\title{
PRZYPADEK GENTE RUTHENI, NATIONE POLONI W GALICJI
}

\author{
Adam Świątek \\ Uniwersytet Jagielloński w Krakowie
}

\section{ABSTRACT}

\section{THE CASE OF GENTE RUTHENI, NATIONE POLONI IN GALICIA}

In this article, the author seeks to answer the question, since when the term gente Rutheni, natione Poloni was used in public space in Galicia. This is the starting point to search for the answer to the question of when the Ruthenians of Polish nationality in Galicia produced the idea defining their identity and worldview. The author tries to reveal when the Ruthenians of Polish nationality made an unsuccessful attempt to carry out their political demands, and how they were perceived in the Polish-Ruthenian society of Galicia. Eventually gente Rutheni, natione Poloni disappeared in the historical process because they had not created an explicit ideology and had not developed a compact elite representing the group of Ruthenians of Polish nationality in the public space. Outstanding individuals from this group functioned within Galician society, but they were more of a tool (the subject) of the Polish policy, rather than an entity.

Key words: gente Rutheni, natione Poloni, Ruthenians of Polish nationality, national identity, Galicia, Polish-Ruthenian relationships

Słowa kluczowe: gente Rutheni, natione Poloni, Rusini narodowości polskiej, tożsamość narodowa, Galicja, stosunki polsko-ruskie

Powszechnie przyjmuje się, że po raz pierwszy pojęcia gente Rutheni, natione Poloni użył Stanisław Orzechowski, renesansowy pisarz wywodzący się z Przemyśla ${ }^{1}$. Pochodził on z rodziny szlacheckiej, jego ojcem był pisarz ziemski przemyski, katolik, a matką córka prawosławnego księdza. Postać Orzechowskiego najczęściej podaje się za najlepszy przykład osoby reprezentującej dwuszczeblową tożsamość

1 Zob. np. Kultura pogranicza wschodniego. Zarys encyklopedyczny, red. T. Budrewicz, T. Bujnicki, J.S. Ossowski, Warszawa 2011, s. 136. 
typu gente Rutheni, natione Poloni, czyli osoby o ruskich korzeniach, która jednocześnie podkreślała przywiązanie do swojej - żeby użyć sformułowań ukutych przez socjologa Stanisława Ossowskiego - ojczyzny prywatnej, czyli Rusi, oraz do ojczyzny ideologicznej, tj. Polski. Paręnaście lat temu podano w wątpliwość, czy faktycznie dla Orzechowskiego lojalność wobec państwa polskiego była ważniejsza od przywiązania do ojczyzny prywatnej - Rusi. Innymi słowy, czy natio było ważniejsze od gens; tudzież czy natio aby na pewno należy rozumieć jako „naród” we współczesnym tego słowa znaczeniu? Amerykański badacz David Althoen, który wysnuł to zastrzeżenie, dodatkowo zakwestionował, czy Orzechowski faktycznie wprowadził do powszechnego użycia pojęcie gente Rutheni, natione Poloni². Według Althoena bowiem $\mathrm{w}$ żadnym $\mathrm{z}$ pism tego renesansowego pisarza nie pada wprost interesujące nas określenie. O ile problem, która ojczyzna, ideowa czy prywatna, była istotniejsza dla pisarza, pozostaje sprawą dyskusyjną i bez wątpienia wymaga rozstrzygnięć ze strony badaczy Polski nowożytnej, o tyle w tym miejscu ważniejsze jest drugie pytanie, dotyczące samego terminu gente Rutheni, natione Poloni. Otóż Orzechowski faktycznie opatrywał karty tytułowe swoich pism epitetami Roxolanus lub Ruthenus, co więcej: na kartach tytułowych kilku jego prac napisanych w połowie XVI wieku przy nazwisku autora pojawia się adnotacja: gente Roxolani, natione vero Poloni $^{3}$, co jest już bardzo zbliżone do interesującego nas terminu. Althoen uważa jednak, że pisma te miały mały zasięg i dotyczyły spraw religijnych, a nie tożsamości etnicznej czy narodowej. Autor ten dochodzi do konkluzji, że najprawdopodobniej termin ten nie był w publicznym użytku aż do XIX wieku. Dokładnie tak sformułowane określenie: gente Rutheni, natione Poloni, odnajdujemy na karcie tytułowej wydanego z rękopisu przez Józefa Korzeniowskiego żywotu Orzechowskiego. Edycja ta została wydrukowana jednak dopiero w 1891 roku$^{4}$ i trudno dziś rozstrzygnąć, jak w rzeczywistości było w oryginale. O Orzechowskim jako gente Rutheni, natione Poloni pisali: na emigracji Karol Sienkiewicz w 1839 roku$^{5}$, a w Galicji w 1870 roku Ludwik Kubala 6 , stąd może od ich prac przyjęło się w historiografii traktowanie XVI-wiecznego humanisty jako egzemplifikację całego zjawiska gente Rutheni, natione Poloni i zarazem autora tego pojęcia.

W każdym razie w ostatnich dekadach XIX wieku interesujące nas określenie było już spopularyzowane i znajdowało się w powszechnym użyciu. Co więcej pełniło wówczas istotną funkcję - było terminem-kluczem, określającym tożsamość czy też światopogląd części mieszkańców Galicji o dwuszczeblowej, rusko-polskiej tożsamości.

2 D. Althoen, Natione Polonus and the Narod szlachecki. Two Myths of National Identity and Noble Solidarity, „Zeitschrift für Ostmitteleuropa-Forschung” 2003, Bd. 52, s. 487-506. Myśl tę rozwiną w swej pracy Serhij Płochij - С. Плохій, Походження слов янських націй. Домодерні ідентичності в Україні, Росії та Білорусі, Київ 2015, s. 185-190.

3 Zob. S. Estreicher, Bibliografia polska, t. 23, Kraków 1910, s. 444-460.

4 Vita Stanislai Orichovii gente Rutheni, natione Poloni ad Ioannem Franciscum Commendonum anno MDLXIV scripta, [Kraków 1891].

${ }^{5}$ K. Sienkiewicz, Skarbiec historii polskiej, t. 1, Paryż 1839, s. 291.

${ }^{6}$ L. Kubala, Stanistaw Orzechowski $i$ wptyw jego na Rzeczpospolite wobec reformacji XVI wieku. Rzecz historyczna, Lwów 1870, s. 59. 
Warto zatem zadać pytanie: od kiedy zaczęto faktycznie używać w przestrzeni publicznej Galicji sformułowania gente Rutheni, natione Poloni na określenie osób pochodzenia ruskiego, które deklarowały przynależność do polskiego narodu? Przed paroma laty $\mathrm{w}$ innym miejscu starałem się ukazać historię tej formacji w zaborze austriackim, jej najważniejszych działaczy i ich dokonania ${ }^{7}$. W niniejszym tekście będę się natomiast starał zwrócić uwagę na ten moment w historii Galicji, kiedy funkcjonująca od setek lat na obszarze szlacheckiej Polski dwuszczeblowa tożsamość przeistoczyła się $\mathrm{w}$ świadomie artykułowaną ideę funkcjonującą przez jakiś czas także w życiu politycznym.

Epoka zaborów przypadająca na okres nowoczesności, czy - mówiąc inaczej modernizacji w dziejach Europy, wiązała się w przypadku obszaru dawnej Polski między innymi z procesami przemian o charakterze świadomościowym. W tym czasie nie tylko rozwijała się polska kultura narodowa (głównie pod wpływem polskich romantyków) i powiększała się w społeczeństwie grupa osób posiadających świadomość przynależności do polskiego narodu, wykraczając poza górne warstwy społeczeństwa porozbiorowego, ale równocześnie, od lat 30. XIX wieku, rodził się także ruski ruch narodowy. Przez zaledwie kilka dekad przeszedł on najważniejsze etapy procesu narodotwórczego, od fazy językowo-kulturalnej po fazę polityczną ${ }^{8}$. Wspólnota etniczna wyłoniła z siebie najpierw elity społeczno-kulturalne, badające ruski język i zwyczaje, następnie zaś - wraz z pojawiającymi się możliwościami politycznymi elity polityczne (początkowo głównie związane z Cerkwią greckokatolicką, później już nie tylko cerkiewne), które podjęły się zadania obrony tegoż języka i postulowały równouprawnienie ludności ruskiej (greckokatolickiej) z ludnością polską (łacińską) w zaborze austriackim. Ostatnim etapem było podjęcie przez świadomą już swej narodowej odrębności ruską elitę polityczną dzieła „unarodowienia”, a więc zaszczepienia idei narodowej wśród ruskiego etnosu. Dodajmy, że proces ten był stymulowany przez konkurencyjnie rozwijające się tendencje: rusofilską i słabnącą już na sile, ale wciąż obecną w życiu politycznym Galicji - polską.

$\mathrm{Na}$ początku wieku nosicielem polskiej świadomości narodowej była przede wszystkim szlachta, ale w pewnym zakresie także mieszczaństwo i duchowieństwo. Z każdą dekadą szeregi uświadomionej narodowo ludności polskiej rozszerzały się, czemu nie przeszkodziła ani germanizacja, ani zacofanie galicyjskiej prowincji. Polacy jako tak zwany naród historyczny rozpoczynali okres nowoczesności z zupełnie innego pułapu aniżeli Rusini. Stopień rozwoju obu ruchów narodowych był zatem nieporównywalny. Gdy galicyjscy Polacy udawali się na pomoc powstańcom

Zob. A. Świątek, Gente Rutheni, natione Poloni. Z dziejów Rusinów narodowości polskiej w Galicji, Kraków 2014.

8 Używam tutaj pojęć zaproponowanych przez Józefa Chlebowczyka - zob. J. Chlebowczyk, O prawie do bytu malych i młodych narodów. Kwestia narodowa i procesy narodotwórcze we wschodniej Europie Środkowej w dobie kapitalizmu (od schyłku XVIII do początków XX w.), Warszawa-Kraków 1983, s. 23, 38-56. 
listopadowym do Kongresówki, to Rusini znajdowali się dopiero na etapie wspólnoty etnicznej. Działalność najpierw polskich badaczy folkloru wschodniogalicyjskiej wsi, a następnie literackie poszukiwania pierwszych inteligentów ruskich zaowocowały zaś zebraniem pierwszych tomów ruskiej poezji i próbami kodyfikacji języka.

W dobie romantyzmu, w latach 30. i 40., Polacy i Rusini uruchomiali zupełnie odmienne projekcje ideowe. Adam Mickiewicz, niekiedy opisywany w literaturze przedmiotu jako gente Lithuanus, natione Polonus (choć to pojęcie bynajmniej nie jest historyczne), głosił w Księgach pielgrzymstwa polskiego, że „Litwin i Mazur bracia są” i - dalej - że: „Nazwisko ich jedne jest, nazwisko Polaków”, a Józef Bohdan Zaleski w Modlitwie za Polska dodawał: „Litwa-Ruś-Polska - trójlistny to bratek"10. Pamięć o związku Polski i Litwy stopniowo zatem rozszerzała się o trzeci komponent - Ruś, a to głównie przy udziale mieszkańców szeroko rozumianych ziem ruskich. W tym trójczłonowym kształcie dawne państwo zaistniało w wyobraźni świadomej części polskiego społeczeństwa jako Rzeczpospolita nie tylko Polski i Litwy, ale także i Rusi. Idee te, z początku mające tylko postać literackiej kreacji, znajdowały przełożenie w programach ideowych galicyjskich konspiracji od lat 30 . XIX wieku. Do działalności spiskowej włączali się Rusini, na przykład alumni seminarium greckokatolickiego w Przemyślu czy ruscy urzędnicy. Spośród znanych potem Rusinów narodowości polskiej wystarczy wymienić takie osoby jak późniejszy aktywista Soboru Ruskiego Julian Horoszkiewicz czy poseł Sejmu Krajowego II, III i IV kadencji Michał Popiel. Był to jednak czas, kiedy pojęcie odrębnej od polskiej narodowości ruskiej jeszcze nie istniało. Dodajmy, że sam termin gente Rutheni, natione Poloni w tym czasie również nie funkcjonował w powszechnym użyciu, bo nie było jeszcze nawet takiej potrzeby, by akcentować tego typu określenia. Przed 1848 rokiem w ogóle nie przewidywano, żeby gente Ruthenus mógł nie być natione Polonus, wszak wierzono, że Polska odrodzi się w swoich granicach sprzed 1772 roku, a naród będzie dalej jeden - polski.

Czy zatem stosowanie pojęcia gente Rutheni, natione Poloni byłoby nieuprawnione, gdy mowa o pierwszej połowie XIX wieku? Wręcz przeciwnie, tego typu dwuszczeblowa tożsamość przecież cały czas istniała, stanowiąc kontynuację zjawiska z czasów polskich. Dotyczyła przede wszystkim szlachty - i to nie tylko bogatego ziemiaństwa, w większości spolonizowanego, lecz także szlachty średniej i drobnej, która w swej pamięci/tradycji rodzinnej przechowywała przywiązanie zarówno do ruskich korzeni, jak i do służby dla dawnego państwa polskiego. Dla niej idea odbudowy Polski stanowiła naturalną perspektywę, a o ukraińskim projekcie państwotwórczym nie było wówczas mowy. Oprócz szlachty przywiązanie do Polski zaczęły w tym czasie wykazywać także nowe kręgi społeczne - rodząca się dopiero inteligencja $^{11}$. Mowa tu o urzędnikach, adwokatach, nauczycielach, pisarzach, publicystach, naukowcach i innych przedstawicielach wolnych zawodów. Miejscem ich działania

9 A. Mickiewicz, Księgi narodu polskiego i pielgrzymstwa polskiego, Paryż 1832, s. 72.

10 B. Zaleski, Poezija, Paryż 1841, s. 103.

11 Na tę dwutorowość kształtowania się formacji gente Rutheni, natione Poloni zwrócił uwagę w swym artykule już przed ponad 20 laty Andrzej A. Zięba, Gente Rutheni, natione Poloni [w:] Prace Komisji Wschodnioeuropejskiej, t. 2, red. R. Łużny, A.A. Zięba, Kraków 1995, s. 61-77. 
i oddziaływania stała się przestrzeń miejska, a w drugiej połowie XIX wieku także wiejska, co również przyczyniło się do rozszerzania idei polskiej wśród szerszych warstw społecznych. Nie można też zapominać o duchownych greckokatolickich, ponieważ Cerkiew unicka była $\mathrm{w}$ znacznym stopniu spolonizowana, a proces ten został zahamowany dopiero w 1848 roku.

Mamy zatem do czynienia ze szlachtą greckokatolickiego obrządku, która swoje przywiązanie do Polski wykazała, choćby biorąc udział w walkach doby napoleońskiej (za przykład może tu posłużyć Józef Matkowski, członek Rady Ministrów Księstwa Warszawskiego i żołnierz biorący udział w wyprawie moskiewskiej ${ }^{12}$ ), jak i z rodzącą się inteligencją. W tym drugim przypadku warto podać często przytaczany w literaturze przykład Józefa Doboszyńskiego, urzędnika z Sambora. Jego wspomnienia najlepiej oddają stan sprzed 1848 roku:

Sambor był i został miastem czysto polskim i wśród młodzieży nie znano wtedy podziału na Polaków i Rusinów, bez względu na obrządek. Do r. 1848 każdy człowiek z wyższą inteligencją uważał się za Polaka, identyfikowanie narodowości z obrządkiem nie miało miejsca. Synowie drobnej szlachty zagonowej w pobliżu Sambora luźnie osiadłej, zwanej pospolicie chodaczkową, którzy przeważnie przynosili z domu mowę ruską, po krótkim pobycie w mieście mówili, mimo niemieckich szkół, po polsku i szczycili się polskim szlachectwem, synowie zaś księży ruskich przynosili już z domu znajomość języka polskiego i sami księża ruscy z lepszą inteligencją używali w domu tegoż języka ${ }^{13}$.

Sytuacja zmieniła się diametralnie w roku 1848, kiedy środowiska duchownych skupione wokół soboru św. Jura we Lwowie przygotowały swój lojalistyczny, sprzeczny z postulatami lwowskich demokratów adres do tronu cesarskiego. Duchowieństwo greckokatolickie, oczywiście niecałe (przede wszystkim hierarchia), podążyło po raz pierwszy odrębną drogą, budując podwaliny ruchu politycznego, dzięki którym mogło się stać elitą ruskiej narodowości ${ }^{14}$. Pozycję tę ze zmiennymi sukcesami utrzymało niemal do ostatnich dekad XIX wieku. Cały problem roku 1848 i zarysowania się wówczas konfliktu polsko-ruskiego zasadzał się na pytaniu o to, kto ma przewodzić wschodniogalicyjskiej ludności ruskiej: unickie duchowieństwo, polska szlachta mieszkająca na Rusi, a może galicyjscy demokraci? Te dwa ostatnie obozy nie pozostały bezczynne wobec ruchu hierarchii greckokatolickiej i również podjęły działania polityczne. Ich owocem było sporządzenie Adresu Rusinów, bodaj najważniejszego dokumentu dla całej formacji gente Rutheni, natione Poloni. Został on przygotowany jako alternatywa dla postulatów środowisk ruskich skupionych wokół

12 J. Matkowski, Zbiór niektórych szczegółów życia mego, przedm. R. Grabowski [w:] Pamiętniki z lat 1792-1849, oprac. R. Grabowski, Wrocław 1961, s. 95-176. Życiorys Matkowskiego podaje B. Łopuszański, Matkowski Józef [w:] Polski stownik biograficzny, t. 20, Wrocław-WarszawaGdańsk-Kraków 1975, s. 203.

13 J. Doboszyński, Pamiętnik [w:] Pamiętniki urzędników galicyjskich, przyg. do dr. I. Homola, B. Łopuszański, Kraków 1978, s. 364-365.

14 Szerzej o roli duchowieństwa greckokatolickiego w kształtowaniu się ruskiej narodowości w Galicji zob. B. Wójtowicz-Huber, „Ojcowie narodu”. Duchowieństwo greckokatolickie w ruchu narodowym Rusinów galicyjskich (1867-1918), Warszawa 2008. 
soboru św. Jura. W adresie tym znalazły się słowa definiujące podstawy politycznego działania, a zatem i światopoglądu Rusinów narodowości polskiej:

My bowiem kraj przez nas zamieszkały jako wspólną z Polakami ojczyznę, Polaków, z którymi nas nierozdzielne węzły dziejów, familii i zwyczajów łączą, jako braci naszych uważamy, i z nimi tylko losy tejże wspólnej ojczyzny naszej dzielić pragniemy ${ }^{15}$.

Następnym krokiem było powołanie organizacji zrzeszającej powstałe środowisko polityczne - Soboru Ruskiego ${ }^{16}$, który miał się stać przeciwwagą dla Hołownej Ruśkiej Rady, reprezentującej greckokatolicką hierarchię, a pomocą dla Centralnej Rady Narodowej, organu dotychczas starającego się o rolę reprezentanta całej ludności Galicji. Sobór Ruski skupiał i miał realizować - choć ze słabym skutkiem - postulaty badanej tutaj grupy Rusinów narodowości polskiej. Najważniejszym osiągnięciem tego organu było wysłanie własnej delegacji na Zjazd Słowiański w Pradze w czerwcu 1848 roku, gdzie jego członkowie rywalizowali z delegatami Hołownej Ruśkiej Rady, aspirując do roli oficjalnego reprezentanta ludności ruskiej w Galicji. Wypracowana wówczas ugoda, mająca regulować polsko-ruskie stosunki w zaborze austriackim i odwlekająca udzielenie odpowiedzi na pytanie o ewentualny podział Galicji na dwie prowincje, co stanowiło owoc działań między innymi członków Soboru Ruskiego, nie doczekała się jednak wprowadzenia w życie ${ }^{17}$. Rusini narodowości polskiej oraz Polacy wspierający tę formację wydali natomiast wówczas sporo pism, publikowali w prasie, a nawet utworzyli swój własny organ prasowy - „Dnewnyk Ruskij”. Redagował go niedawny działacz młodoruski Jan Wagilewicz. Nie było to jednak środowisko jednolite, co poskutkowało zarysowaniem się konfliktu w jego szeregach. Wszak w skład Soboru Ruskiego wchodzili zarówno polscy (tudzież z dawna spolonizowani) ziemianie z Rusi (Aleksander, Julian i Włodzimierz Dzieduszyccy, Józef Puzyna, Ludwik Stecki), jak i inteligencja obrządku greckokatolickiego (Julian Horoszkiewicz, Mikołaj Zyblikiewicz, Zygmunt Sawczyński, Jan Zachariasiewicz), a nawet osoby niemające w ogóle ruskich korzeni, choć znające język ruski i agitujące w przeszłości na ruskiej wsi. Taką postacią był Kasper Cięglewicz, syn Polaka i Ormianki. To między nim a częścią członków Soboru Ruskiego zarysował się spór, który poskutkował późniejszym rozbiciem grupy. Cięglewicz nie tylko nie uważał Rusinów za naród, ale nawet odmawiał ruskiemu prawa do określania go mianem języka, czemu dał wyraz na łamach broszury Rzecz czerwono-ruska ${ }^{18}$.

15 Adres Rusinów, [Lwów 1848].

16 O Soborze Ruskim pisze lwowski historyk Marian Mudryj. Zob. m.in. М. Мудрий, Руський собор 1848 року. Організація та члени, „Україна. Культурна спадщина, національна свідомість, державність” (Львів) 2008, вип. 16: Юбілейний збірник на пошану Івана Патера, s. 107-126; idem, ,„Jesteśmy rozdwojonymi czlonkami jednego ciała”. До питання про відносини між Головною Руською Радою і Руським Собором 1848 року [w:] Записки Наукового товариства імені Шевченка, т. 265: Праиі Історично-філософської секиії, Львів 2013, s. 54-80; idem, Руський собор 1848 року. Історіографічний та джерелознавчий огляд, „Вісник Львівського університету. Серія книгознавство, бібліотекознавство та інформаційні технології” (Львів) 2014, вип. 8, s. 193-206.

17 Szerzej w: A. Świątek, Polacy i Rusini o Zjeździe Slowiańskim w Pradze w 1848 roku, „Historica. Revue pro historii a př́buzné vědy" R. 7, 2016, nr 1, s. 23-52.

18 K. Cięglewicz, Rzecz czerwono-ruska 1848 roku, Lwów 1848. 
Mówiąc w skrócie: Cięglewicz stał na stanowisku, że Rusini stanowią jedynie regionalną społeczność zawierającą się w narodowości polskiej i w związku z tym muszą się podporządkować. Występował on przeciwko rozwojowi języka ruskiego, bowiem skutkowałoby to osłabieniem naturalnego procesu polonizacji Rusinów. Doczekał się za to krytyki na łamach wspomnianego „Dnewnyka Ruskiego"19. Mimo swojej rewolucyjnej przeszłości Cięglewicz ze swoimi poglądami znajdował się zatem bliżej polskiego ziemiaństwa w Galicji Wschodniej aniżeli Rusinów, wśród których i z którymi agitował w przeszłości. Nie wchodząc w szczegóły tego sporu, warto podkreślić jedno: krytykowana przez Cięglewicza postawa reprezentowana przez ówczesnych Rusinów narodowości polskiej to zjawisko, które nazwalibyśmy połowiczną asymilacją, zatrzymaniem się w pół drogi między akulturacją a asymilacją ${ }^{20}$. Tożsamość typu gente Rutheni, natione Poloni charakteryzowała się świadomym pozostawaniem przy ruskich cechach kulturowych, ale jednocześnie aprobatą uwarunkowanego historycznie wiązania z polskością swoich dalszych losów.

Klęska Wiosny Ludów w Galicji i zawiedzione nadzieje w zasadzie wszystkich powstałych wówczas stronnictw politycznych w przypadku środowiska Soboru Ruskiego i „Dnewnyka Ruskiego” poskutkowały niedokończeniem projektowania programu politycznego tegoż obozu i - co okazało się bardziej brzemienne w skutki - brakiem wykrystalizowania się zwartej elity tegoż środowiska.

W latach 50. XIX wieku, mimo powrotu rządów absolutystycznych w Galicji, byli działacze Soboru Ruskiego - ale nie tylko oni, bo w życiu publicznym pojawiły się także inne osoby o dwuszczeblowej rusko-polskiej tożsamości - wykazywali aktywność w przestrzeni społecznej, starając się w miarę ograniczonych możliwości realizować stawiane przed sobą zadania $\mathrm{w}$ duchu wyznawanych wartości. Te jednostki, bo o szerszym ruchu nie mogło być mowy, łączyły zwłaszcza trzy postawy: 1) podkreślanie swoich ruskich korzeni i obrona ruskiego języka, obrządku i tradycji; 2) niechęć wobec obozu świętojurskiego, zwłaszcza ze względu na oglądanie się na Rosję; 3) współpraca z Polakami i ogólna aprobata dla swojego związku z szeroko rozumianą polskością. Walka z obozem rusofilskim odbywała się nie bez zaangażowania najwyższych władz, a przede wszystkim Agenora Gołuchowskiego. Negatywny stosunek tego namiestnika Galicji do jedynego wówczas pisma ruskiego „Zorji Hałyćkiej”, przyjmującego pod redakcją Bohdana Didyćkiego i Seweryna Szechowycza rusofilski profil, a następnie osadzenie w nim nowych redaktorów, w tym Platona Kosteckiego ${ }^{21}$, oraz próba narzucenia językowi ruskiemu czcionki łacińskiej, czego próbował w 1859 r. dokonać rękami Euzebiusza Czerkawskiego ${ }^{22}$, pokazuje, że grupa Rusinów narodowości polskiej wciąż była raczej przedmiotem

19 De szczo do izjasnenija, „Dnewnyk Ruskij” 1848, nr 3 z 1 (13) IX, s. 2.

20 Wspomniany wcześniej Chlebowczyk nazywa to zjawisko fenomenem półasymilacji czy też hybrydyzacji kulturowej, zob. J. Chlebowczyk, op. cit., s. 62.

21 Pisze o tym Iwan Franko: I. Франко, Стара Русь [w:] Зібрання творів у п ятдесяти томах, т. 37: Літературно-критичні праџі (1906-1908), Київ 1982, s. 96 i n. Zob. też: I. Орлевич, Ставропігийський інститут у Львові (кінеиь XVIII-60-і рp. ХIX cm.), Львів 2000, s. 108-115.

22 B. Łoziński, Agenor hrabia Goluchowski w pierwszym okresie rządów swoich (1846-1859), Lwów 1901, s. 182-187. 
niż podmiotem polityki. Zauważamy jednak, że kariery obu wspomnianych Rusinów, Kosteckiego i Czerkawskiego (odpowiednio: dziennikarska i polityczna), a także wielu im podobnych, mogły się powieść właśnie dzięki realizowaniu w swoim życiu postawy typu gente Rutheni, natione Poloni. Od tego momentu nie może być już mowy o konsolidacji środowiska ani o realizowaniu przez nie jakiejś linii politycznej. W przestrzeni publicznej działały jednostki i właściwie były one narzędziem polskiej polityki tego czasu.

W zasadzie jedyną szansą dla ponownego, politycznego zaistnienia przez tę grupę mogło być tylko powstanie styczniowe, w trakcie którego Rząd Narodowy umieścił na swych pieczęciach i chorągwiach obok polskiego Orła i litewskiej Pogoni także ruskiego Archanioła Michała. Należy to jednak uznać za działanie czysto symboliczne, co zresztą potwierdziły dyskusje wysłannika Rządu Narodowego - Władysława Majewskiego - z Rusinami, które miały na celu wciągnięcie do powstania ludności ruskiej. Rozmowy te wykazały jedynie nieufność strony polskiej do Rusinów, i to mimo że gospodarzem spotkania był greckokatolicki ksiądz Stefan Laurysiewicz, który zasłynął przecież organizacją polsko-litewsko-ruskiej manifestacji patriotycznej w Horodle w 1861 roku $^{23}$, a Rusinów reprezentował bodaj najbardziej propolsko nastawiony ruski poseł niedawno powołanego Sejmu Krajowego, a niegdyś członek Soboru Ruskiego - Julijan Ławrowśkyjj ${ }^{24}$. Do powstania nie poszedł zatem żaden oddział ruski, a politycy ruscy w Galicji pozostali na nie obojętni, chociaż odnotowano spontaniczny udział pewnej liczby Rusinów w powstaniu ${ }^{25}$.

W tym czasie rozdźwięk między Rusinami a Polakami w zaborze austriackim postępował. Znacząco przyspieszył on wraz z demokratyzacją życia publicznego, a więc kolejnymi latami funkcjonowania Sejmu Krajowego, tworzeniem nowego ustawodawstwa dla Galicji i obejmowaniem w niej władzy przez Galicjan. Równolegle postępowały natomiast uświadomienie narodowe ruskiego duchowieństwa niższego szczebla i jego stopniowe oddalanie się od Polaków. Popularność zdobywał równocześnie nurt rusofilski ${ }^{26}$, którego admiratorzy byli jeszcze bardziej niechętnie ustosunkowani do sprawy polskiej aniżeli stronnicy Hołownej Ruśkiej Rady z 1848 roku.

Ówczesny stan stosunków wśród ludności ruskiej zdiagnozował w swej pracy zatytułowanej $W$ sprawie ruskiej wspomniany już wcześniej Platon Kostecki ${ }^{27}$. War-

23 W. Śladkowski, Pod znakiem Orła, Pogoni i Michała Archanioła. Idee unijne i federacyjne $w$ dobie powstania styczniowego [w:] Unia lubelska. Unia Europejska, red. I. Hofman, Lublin 2010, s. $132-149$.

24 A. Słotwiński, Wspomnienia z niedawnej przeszłości, cz. 1: 1860-1871, Kraków 1892, s. 117. W literaturze przedmiotu zob. szerzej: M. Mudryj, Powstanie styczniowe a środowisko gente Rutheni, natione Poloni w Galicji [w:] Powstanie styczniowe. Odniesienia, interpretacje, pamięć, red. T. Kargol, Kraków 2013, s. 72; A. Świątek, Gente Rutheni..., s. 280-281.

25 A. Świątek, Gente Rutheni..., s. 286-293.

${ }^{26}$ Szerzej na ten temat: W. Osadczy, Święta Ruś. Rozwój i oddzialywanie idei prawosławia $w$ Galicji, Lublin 2007; A.В. Вендланд, Русофіли Галичини. Українські консерватори між Австрією та Росією 1848-1915, перекл. Х. Назаркев ич, наук. ред. М. Мудрий, Львів 2015.

27 Львівська національна наукова бібліотека України імені В. Стефаника (dalej: ЛННБУ), ф. 5: Zbiór rękopisów, oп. 1, 3063/II: P. Kostecki, W sprawie ruskiej, [Lwów 1863]. 
to tu dodać na marginesie, że jest to postać szczególnie ważna dla formacji Rusinów narodowości polskiej, ponieważ jego liczne wiersze, niejednokrotnie akcentujące związek Polski, Litwy i Rusi, potwierdzały obecność idei gente Rutheni, natione Poloni w przestrzeni kulturalnej Galicji. Jego wiersz Nasza molytwa napisany w 1861 roku, a opublikowany w odrębnym zbiorze rok później, wielokrotnie przywoływano przy różnych okazjach i traktowano wręcz jako literacki manifest tej grupy. Zresztą pierwsze wersy tego utworu mówią same za siebie:

\author{
Wo imia Otca i Syna - \\ To nasza mołytwa: \\ Jako Trojca tak jedyna \\ Polszcza, Ruś i Łytwa ${ }^{28}$.
}

Powstały natomiast prawdopodobnie w $1863 \mathrm{r}$. tekst $W$ sprawie ruskiej to analiza światopoglądu elit ruskich. Tekst ten niejednokrotnie wspomina o osobach o podobnej jak Kostecki tożsamości. Warto przytoczyć tu niektóre sądy autora, bo mimo że reprezentował on polski nurt w ruchu ruskim, to jednak starał się patrzeć krytycznie na ówczesne realia. Opisując poszczególne warstwy społeczeństwa ruskiego, notował: „Szczerze za Polską jest księży bardzo mało, mojem zdaniem ledwie 20ta część; reszta marzy o panslawizmie, a po największej części jest indyferentna. Czy jednak przychylni dla Polski posunęliby się aż do ofiar z poświęceniem bezwzględnem, o tem wątpię w ogóle"29. Dalej podkreślał, że to głównie ci starsi księża optowali za Polską, co odróżniało ich na tle młodych duchownych unickich. Kolejną „polską grupę” mieli stanowić urzędnicy: „Urzędnicy albo serdecznie, ile im stosunek do rządu pozwala, sprzyjają Polsce, albo myśląc że idą w myśl rządu, są przeciwni Polsce, albo są indyferentni; o panslawizmie, chyba gdzie wyjątkowo nie ma między nimi mowy" ${ }^{30}$. Najwięcej Rusinów narodowości polskiej było, według Kosteckiego, w warstwie mieszczańskiej: „Sądzę że małomieszczanie są w całem znaczeniu Polakami (z wyjątkiem podobno Kołomyi); rzemieślnicy obu rządów po większej części; a diacy idą za gromadą albo księdzem”31. O chłopach natomiast pisał, iż „masa” wie, że była polska, a teraz jest austriacka, inteligencja ruska zaś w tym czasie nie miała jeszcze wpływu na włościan, dlatego też potencjalne nawoływanie do „hajdamaczyzny", czyli dokonania krwawej rzezi na panach (jak w przypadku rabacji), nie spotkałoby się z posłuchem ${ }^{32}$. Diagnozy te okazały się prawdziwe, ale stopniowo przemiany konstytucyjne w monarchii, a zatem reaktywacja życia politycznego w Galicji i związana z tym aktywność inteligencji ruskiej zmieniały ten stan rzeczy. Co istotne, autor opisując Rusinów narodowości polskiej w 1863 roku, nie używał jeszcze interesującego nas pojęcia: gente Rutheni, natione Poloni. Gdyby było ono już w powszechnym użytku, niewątpliwie posłużyłby się nim w swojej pracy, chcąc opisać reprezentowaną przez samego siebie tożsamość.

\footnotetext{
28 P. Kostecki, Poezyi, Lwów 1862.

29 ЛННБУ, ф. 5, оп. 1, 3063/II, k. 2.

30 Ibidem, k. 3.

31 Ibidem, k. 4.

32 Ibidem, k. 5-6.
} 
Kto zatem jest autorem tego określenia i kto pierwszy go użył w XIX wieku? Zapewne odpowiedź na te pytania długo jeszcze pozostanie zagadką, niemniej jednak w źródłach od początku lat 60. XIX stulecia takowe określenie zaczęło się coraz częściej pojawiać w przestrzeni publicznej. Można zatem podejrzewać, że spopularyzowanie hasła gente Rutheni, natione Poloni nastąpiło w związku z przemianami ustrojowymi w monarchii habsburskiej po 1860 r. i pojawieniem się tym samym okazji do konfrontacji między Polakami i Rusinami, w którym to konflikcie Rusini narodowości polskiej początkowo odgrywali nawet pewną rolę. Wówczas to część polskich posłów (także tych pochodzenia ruskiego) podjęła się trudu zahamowania rozwoju ruskiej narodowości czy to w kierunku narodowym, czy przede wszystkim rusofilskim (a w zasadzie postulowanego przez nich podziału Galicji i równouprawnienia językowego, które to postulaty rozwój ów znacznie by przyspieszyły), stąd etykietą tą posługiwali się nie tylko Rusini narodowości polskiej, ale w ten sposób przezywała ich także strona przeciwna.

Odnowienia konfliktu między Rusinami (obozem świętojurskim) a Polakami należałoby się doszukiwać na przełomie lat 1860/1861. Wtedy to mieszkańcy Galicji wystosowali 4 stycznia 1861 r., a więc już po wydaniu dyplomu październikowego, adres do tronu z postulatem utworzenia Sejmu Krajowego z szerokimi kompetencjami; jednocześnie apelowano o wprowadzenie języka polskiego do galicyjskiej administracji i szkolnictwa. Na temat równouprawnienia języka ruskiego również się wypowiadano, ale dość enigmatycznie. Gdy 11 stycznia 1861 r. do Wiednia przybyła kolejna (tym razem ruska) delegacja, na czele z nowym metropolitą greckokatolickim Lwowa, abp. Hryhorijem Jachymowyczem, która oprócz zapewnienia o lojalności galicyjskich Rusinów względem tronu miała także domagać się szczególnej pozycji dla języka ruskiego we wschodniej Galicji, w polskiej prasie odezwały się krytyczne głosy. W jednym z numerów „Przeglądu Powszechnego” z tego czasu odnajdujemy tekst zachwalający ten pierwszy adres (z 4 stycznia), bowiem ,zasada narodowa «gente Mazurus, Ruthenus ant Judeaens, natione autem Polonus», najsilniejsze w tym adresie znalazła poparcie" 33 . Podkreślano zatem, że adres ten był głosem wszystkich mieszkańców Galicji pochodzenia mazurskiego, ruskiego czy żydowskiego, którzy stali na stanowisku narodowej jedności, podczas gdy deputacja Jachymowycza dla autora wspomnianego tekstu była głosem nawet nie Rusinów, a jedynie określonych środowisk związanych z hierarchią greckokatolicką we Lwowie.

Nie jest możliwym jednak stwierdzenie, czy było to pierwsze w galicyjskiej przestrzeni publicznej użycie pojęcia gente..., natione... Bez wątpienia w latach 60. XIX wieku zaczęło się ono popularyzować dzięki prasie oraz dyskusjom parlamentarnym na forum utworzonego w 1861 r. Sejmu Krajowego we Lwowie. Tłem był konflikt posłów polskich i ruskich o język obrad, a w dalszej perspektywie całej administracji Galicji. W braku równouprawnienia języka ruskiego politycy Rusini dopatrywali się upośledzenia narodowości ruskiej w prowincji. Sytuację zresztą dodatkowo komplikował fakt nie uznawania Rusinów za naród przez wielu posłów polskich ${ }^{34}$.

${ }^{33}$ Przegląd dzienników wiedeńskich, „Przegląd Powszechny” 1861, dodatek do nr. 13 z 29 I.

34 Por. J. Moklak, Spór polsko-ukraiński o język obrad sejmu galicyjskiego (1865-1866). Wnioski Antona Petruszewycza i Aleksandra Borkowskiego. Przyczynek do ksztaltowania się nacjonalizmów 
I tak na trzecim posiedzeniu sejmu I kadencji w roku 1865 ruski poseł Stepan Kaczała zarzucał Polakom chęć polonizacji Rusinów i zwracał uwagę na upośledzone położenie ludności ruskiej. Argumentował, że ,[...] jak dawno tylko tej stawawsia zdolnym do wsego, kto buw łat. obrjadku, na szczo dowody mohu prytoczyty, tak i nyni Rusyn ne może sia nihde dopchaty osobływo hde Polaki majut szczość skazaty, chiba jest tak zwanyj gente Ruthenus natione Polonus". Na to odpowiedział mu z przekąsem Mikołaj Zyblikiewicz: „zapytam go [Stepana Kaczałę - przyp. A.Ś.] tylko, czem on był do roku 1848, jeżeli nie gente Ruthenus, a natione Polonus" ${ }^{35}$. Od tego czasu sformułowanie gente Rutheni, natione Poloni na stałe weszło do języka polityki.

Kolejnym zamanifestowaniem tożsamości typu gente Rutheni, natione Poloni w sejmie stała się wypowiedź posła Kazimierza Grocholskiego, który w trakcie emocjonującej dyskusji sejmowej miał powiedzieć: ,[...] prawda, Panowie, jam gente Rutenus, natione Polonus, jakoście tutaj ironicznie wyrzekli, ale was wszystkich nie uważam, tylko jako gente Rutenos, natione Polonos!"36. Warto ukazać kontekst tej wypowiedzi: w trakcie dyskusji o postulacie podziału Galicji Grocholski odmawiał Rusinom prawa do nazywania siebie odrębnym narodem. Należy jednak mieć na uwadze fakt, że sam Grocholski nie był etnicznym Rusinem, a polskim ziemianinem zamieszkałym na obszarze dawnej Rusi Czerwonej. Posługiwał się zatem pojęciem gente Ruthenus, natione Polonus, rozumiejąc je w nieco odmienny sposób, aniżeli zwykło się je pojmować w późniejszym czasie. Ruskość dla Grocholskiego oznaczała wywodzenie się z obszaru dawnego województwa ruskiego, a nie przywiązanie do ruskiej kultury czy języka. Analogicznie po tę formułę sięgali także inni ziemianie wschodniogalicyjscy.

W tym samym czasie gente Rutheni rozumiano też dosłownie - nie jako pochodzenie z Rusi, ale bycie ruskiego rodu, czyli bycie etnicznym Rusinem. W takim ujęciu etykietą gente Rutheni, natione Poloni posługiwał się wspomniany już poseł Mikołaj Zyblikiewicz, późniejszy prezydent Krakowa i marszałek Sejmu Krajowego. Ignacy Baranowski w swoim pamiętniku odnotował interesujący fragment wypowiedzi Zyblikiewicza (niestety nie wiadomo z którego roku, ale na pewno z lat 60 . XIX w.):

Zyblikiewicz wpadał w gniew, gdy poruszano kwestję rusińską w Galicji. Słyszałem, jak mówił z pasją do jakiegoś oponenta: „no, jestem Rusinem, czy z Rusinów, więc cóż chcesz, żebym $\mathrm{z}$ tobą przestał gadać po polsku, żebym się odzywał jak Kowbasiuk lub jak ten... Kuziemski po rusku? Jestem gente ruthenus, natione polonus”. Lagodny Hubicki uspakajał: „Nie gniewaj

w Galicji Wschodniej, „Biuletyn Ukrainoznawczy” 2003, t. 9, s. 40-51; M. Mudryj, Dylematy narodowościowe w Sejmie Krajowym galicyjskim (na przykładzie postów formacji gente Rutheni natione Poloni) [w:] Ukrainskie tradycje parlamentarne. XIX-XXI wiek, red. J. Moklak, Kraków 2006, s. 59-94.

35 Stenograficzne sprawozdania z trzeciej sesyi Sejmu Krajowego Królestwa Galicyi i Lodomeryi wraz z Wielkiem Księstwem Krakowskiem w roku 1865-1866, t. 1: Posiedzenie 1-40, Lwów 1865-1866, s. 460 (25. posiedzenie z 23 I 1866).

36 Ibidem, t. 2: Posiedzenie 41-80, Lwów 1865-1866, s. 1618 (71. posiedzenie z 18 IV 1866). 
się, p. Mikołaju, to nic nie pomoże!”, i dodawał, że należy wyrozumieć, jeżeli są Rusini, którzy chcą być ,gente et natione Rutheni" ${ }^{37}$.

W Sejmie Krajowym obecność posłów ruskich narodowości polskiej okazała się szczególnie ważna przy okazji prac nad dwiema ustawami de facto polonizującymi szkolnictwo w Galicji. Obie ustawy, o języku w szkolnictwie oraz o Radzie Szkolnej Krajowej, przyjęto w grudniu 1866 roku, ale wywołały one burzliwą dyskusję między Rusinami opcji narodowej a stroną polską ${ }^{38}$. Z jednej strony udowadniano, że Ruś to część dawnej Polski, a język ruski to polskie narzecze, z drugiej oskarżano Polaków o chęć zdominowania Rusinów w Galicji. Niepoślednią rolę w przygotowaniu obu ustaw odegrali właśnie Rusini narodowości polskiej: Zygmunt Sawczyński i Euzebiusz Czerkawski.

Dla historii formacji Rusinów narodowości polskiej znaczenie symboliczne będzie miał rok 1869, kiedy Lwów nie tylko żył jeszcze echem sporów o uchwałę rezolucyjną, ale także zaangażował się w uczczenie 300-rocznicy zawarcia unii lubelskiej ${ }^{39}$. Lwowskie obchody tego jubileuszu wraz z podjętą wówczas inicjatywą sypania kopca Unii Lubelskiej miały połączyć całe społeczeństwo, w tym także ludność ruską. Ona jednak okazała się na tę manifestację obojętna i to mimo zaangażowania w organizację obchodów Rusinów narodowości polskiej, takich jak Platon Kostecki, Dymitr Koczyndyk czy Teofil Merunowicz. Ten ostatni opublikował nawet w dwóch językach, polskim i ruskim, specjalną broszurę poświęconą 300-leciu unii ${ }^{40}$. W niej, ale także w innych drukowanych wówczas tekstach, na łamach prasy, na uroczystych bankietach i oficjalnych spotkaniach czy w teatrze - nieustannie podkreślano zawarty przed trzema stuleciami związek nie tyle Polaków i Litwinów, ile Polaków, Litwinów i Rusinów. Pozytywnego odzewu ze strony ruskich działaczy i prasy jednak nie było. Jubileusz ten, jeśli mowa o stosunkach polsko-ruskich w tym czasie, potwierdził jeszcze raz to, co zweryfikowało kilka lat wcześniej powstanie styczniowe - opcja gente Rutheni, natione Poloni jako preferowany kierunek rozwoju światopoglądu ludności ruskiej w Galicji nie miała już większych szans powodzenia, co nie oznacza, że dla osób reprezentujących tę formację zabrakło miejsca w przestrzeni publicznej. Niemniej jednak w latach 60. XIX wieku scenariusz polski okazał się już nieaktualny dla galicyjskich Rusinów, rozwijających własną narodowość i mierzących się z większym wyzwaniem - orientacją rusofilską swoich współplemieńców. Zauważmy, że żaden z polskich obozów politycznych drugiej połowy XIX wieku

37 [I. Baranowski], Pamiętniki Ignacego Baranowskiego (1840-1862), wyd. A. Wrzosek, Poznań 1923, s. 299.

38 J. Moklak, Stanowisko posłów polskich gente Ruthenus i ruskich (ukraińskich) w Sejmie Krajowym galicyjskim wobec projektu ustawy o języku wykladowym $w$ szkołach ludowych i średnich $w 1866 r$, „Biuletyn Ukrainoznawczy” 2002, t. 8, s. 28-41.

${ }^{39}$ Szerzej na ten temat zob.: P. Sierżęg a, Obchody rocznicy unii lubelskiej na terenie Galicji w 1869 roku [w:] Działalność wyzwoleńcza, red. J. Hoff, Rzeszów 2001, Galicja i Jej Dziedzictwo, t. 15, s. 146192; М. Мудрий, Ідея польсько-украӥнської унії та „Русини польської нації” в етнополітичному дискурсі Галичини 1859-1869 років, „Вісник Львівського університету. Серія історична” 2005, вип. 39-40, s. 134-147; A. Świątek, Gente Rutheni..., s. 350-364.

40 T. Merunowicz, Pamiatka 300-letniej rocznicy unii Lubelskiej 1869 roku, Lwów 1869; idem, Pamiatka 300-litnoj ricznyci unii Lublińskoj 1869 roku, [Lwów 1869]. 
otwarcie nie propagował światopoglądu typu gente Rutheni, natione Poloni, a wręcz przeciwnie - owocem działań galicyjskich konserwatystów krakowskich, trzymających przez długi okres ster władzy w zaborze austriackim, było wsparcie narodowej orientacji wśród Rusinów jako przeciwwagi dla opcji rusofilskiej.

Etykieta gente Rutheni, natione Poloni funkcjonowała jednak w przestrzeni publicznej nadal, także poza Sejmem Krajowym i poza światem polityki. Stała się hasłem określającym specyficzny światopogląd przedstawicieli omawianej tu grupy. W 1871 roku pod pseudonimem „Gente Ruthenus natione Polonus” wydał swoją pracę niegdysiejszy przewodniczący Soboru Ruskiego Julian Horoszkiewicz, która de facto streszczała wyznawane przez niego poglądy ${ }^{41}$. Chociaż w latach 70 . XIX wieku jego rewolucyjny zapał sprzed lat wyraźnie już stopniał, to jednak w dziełku swym, zatytułowanym Podstawa do zgody w narodzie, wyznawał potrzebę zastąpienia Polski stanowej (rycerskiej) przez Polskę równych ludzi. Polskość zatem autor traktował bardziej jako ideę stojącą ponad etnicznym zróżnicowaniem. Analizował przyczyny niezgody polsko-ruskiej w Galicji, jako jej prowodyra wskazując Austrię, ale w dalszej perspektywie wierzył, że ludność ruska w całości stanie się kiedyś gente Rutheni, natione Poloni. Tak się jednak nie stało, a zjawisko gente Rutheni, natione Poloni zamknęło się wewnątrz drobnej jeszcze wówczas warstwy inteligenckiej pochodzenia ruskiego, która dzięki swojemu przywiązaniu do polskości, odcinaniu się od ruskiego obozu narodowego i obozu rusofilskiego, mogła działać w przestrzeni publicznej. Gente Rutheni, natione Poloni robili karierę w polityce (Euzebiusz Czerkawski, Teofil Merunowicz, Michał Popiel, Zygmunt Sawczyński, Mikołaj Zyblikiewicz), administracji, szkolnictwie (Tomasz Polański), dziennikarstwie i na polu literackim (Jan Dobrzański, Julian Horoszkiewicz, Platon Kostecki, Konstanty Srokowski, Jan Zachariasiewicz), nauce (Emilian Czyrniański, Walery Jaworski, Anatol Lewicki) czy w innych wolnych zawodach, chociażby w adwokaturze (Antoni Dąbczański). Można tu wymienić wiele przykładów.

Wyartykułowane w latach 60. hasło gente Ruthenus, natione Polonus jako deklarację swojej tożsamości tudzież światopoglądu głosili najaktywniejsi reprezentanci tej formacji, ale w zasadzie z każdą dekadą coraz bardziej oddalali się oni od swoich ruskich korzeni. Równolegle polski dorobek kulturalny drugiej połowy XIX wieku (literatura, sztuki piękne) przesiąknięty był ideą polsko-litewsko-ruskiej jedności. Odwoływano się do przeszłości, wyławiano z niej przykłady zdarzeń i postaci, które swoim życiem świadczyły o świetności dawnej, wieloetnicznej Rzeczypospolitej Obojga Narodów, a zatem stanowiły kierunkowskaz, jak ma wyglądać przyszła, niepodległa Polska. Ta zaś bez Rusi istnieć nie mogła. Wyobrażenia Polaków rozmijały się zatem z wyobrażeniami Rusinów, zarówno opcji narodowej, jak i rusofilskiej. Ikoną Rusinów narodowości polskiej i piewcą idei gente Rutheni, natione Poloni był zwłaszcza Platon Kostecki, niegdyś ruski literat, następnie polski poeta i dziennikarz, wieloletni redaktor lwowskiej „Gazety Narodowej”. To on w Galicji najdosadniej propagował wizję mającej się w przyszłości odrodzić Rzeczypospolitej Polski, Litwy

${ }^{41}$ [J. Horoszkiewicz], Gente Ruthenus natione Polonus. Podstawa do zgody w narodzie, Lwów 1871. 
i Rusi, czemu wyraz dawał w wielu wierszach jubileuszowych, przedrukowywanych w gazetach w Galicji i w pozostałych zaborach. W latach 80. XIX stulecia nie tylko jego powszechnie etykietowano jako gente Ruthenus, natione Polonus ${ }^{42}$, ale także innych podobnych jemu Rusinów narodowości polskiej. Tego typu określenia odnajdujemy zwłaszcza w różnych wspomnieniach, przede wszystkim pośmiertnych, o poszczególnych zasłużonych dla kraju Rusinach narodowości polskiej. Niejeden autor mowy pogrzebowej, przedrukowywanej w prasie galicyjskiej, stosując określenie gente Ruthenus, natione Polonus, chciał zwięźle scharakteryzować życiową postawę zmarłego ${ }^{43}$. Dochodzimy tu zatem do wniosku, że interesujące nas określenie było przede wszystkim wykorzystywane jako sposób zamanifestowania tej dwuszczeblowej tożsamości, a więc ruskiego pochodzenia i jednoczesnego patriotyzmu polskiego. Sami zainteresowani używali go jednak dość rzadko, a jeśli już, to chcąc podkreślić swój światopogląd wobec osób o odmiennych poglądach. Częściej natomiast tę etykietę przypinali Rusinom narodowości polskiej inni - etniczni Polacy czy też politycy i publicyści ruscy, tyle że kierowali się odmiennymi przesłankami. Pierwsi traktowali to zazwyczaj jako wartość pozytywną, dla drugich owo określenie miało wydźwięk raczej krytyczny, a nawet ironiczny.

$\mathrm{Z}$ czasem także i ruscy narodowcy zaczęli wykorzystywać formułę gente... natio$n e . . . \mathrm{w}$ takim znaczeniu, jaki im był potrzebny. Mianowicie podkreślali, że oni są gente Rutheni i natione Rutheni. Bodaj jako pierwszy - i to jeszcze w 1863 roku - Ostap Łewyćkyj podpisał się jako ,gente Ruthenus, natione także Ruthenus” na złośliwie zadedykowanym Janowi Dobrzańskiemu pamflecie, który miał na celu ośmieszenie powstańców styczniowych ${ }^{44}$. Z kolei w sejmie w 1890 roku Julijan Romanczuk mówił: „My ani gente Rutheni, natione Poloni, ani gente Rutheni, natione Russi, ałe my jeśmo gente Rutheni i natione Rutheni" ${ }^{\prime 4}$. Romanczuk użył konstrukcji gente..., natione..., aby podkreślić tożsamość swego obozu, ale inny poseł ruski - Mykoła Siczynśkyj - posłużył się nią, aby potępić odstępców od narodowości ruskiej: „[...] my musymo nazwaty renehatom toho chto chocze sia zwaty gente Ruthenus natione Polonus, to musymo z takym samym prawom renegatom zwaty toho, szczo

42 Podczas jubileuszu pracy dziennikarskiej Kosteckiego Leon Syroczyński, sam przybyły z ziem ukraińskich, wzniósł toast za jubilata i powiedział: „Ty Gente Ruthenus, natione Polonus, jak ono, etnograficznie ruskie spolszczyliście się tak znakomicie, nie zapominając o swej przyrodzonej mowie". Bankiet na cześć Platona Kosteckiego, „Gazeta Narodowa” (Lwów) 1888, nr 16 z 20 I.

43 Np. Anatola Lewickiego Stanisław Smolka żegnał na pogrzebie następującymi słowami: „Mieliśmy w nim [...] wybitne uosobienie tego pięknego, starego, a ginącego dziś typu: gente Ruthenus, natione Polonus. Kochał on gorąco tę Ruś swoją, ale kochał ją w Polsce”. Pogrzeb śp. prof. Dra Anatola Lewickiego, „Czas” 1899, nr 98 z 29 IV, s. 3.

${ }^{44}$ [O. Łewyćkyj] Ostap Kowbasiuk, gente Ruthenus, natione także Ruthenus, Uciekinierzy, poemat à la „Konrad Wallenrod”, Lwów 1863. Szydercza dedykacja dla Dobrzańskiego, jednego z najaktywniejszych Rusinów narodowości polskiej w Galicji, zaczynała się słowami: „Jego mości Janowi IV. królowi in spe Polski w dawnych granicach, in praesens Mecenasowi in partibus infidelium, id est: perekińczyków; sławnemu znawcy geografiji polskiej [...]".

45 Stenograficzne sprawozdania z drugiej sesyi szóstego peryodu Sejmu krajowego Królestwa Galicyi i Lodomeryi z Wielkiem Księstwem Krakowskiem z roku 1890, Lwów 1890, s. 950 (23. posiedzenie z $25 \mathrm{XI})$. 
chocze zwaty sia gente Ruthenus natione Russus"46. Gente Rutheni, natione Poloni funkcjonowali zatem w ruskiej narracji politycznej właśnie jako renegaci, czy też perekinczyky (перекинчики) ${ }^{47}$.

Summa summarum tożsamości typu gente Rutheni, natione Poloni zaczęli w końcu zaprzeczać także niektórzy Polacy, uważając tę formułę za zjawisko anachroniczne i wymagające definitywnego zakończenia, oczywiście na rzecz pełnej asymilacji. Jan Czerwiński, narodowy demokrata, w 1891 roku pisał tak:

Czem jest Polak zniemczony lub zmoskwiczony, jeżeli się taki znajdzie? Wszakże już nie Polakiem, lecz Niemcem lub Moskalem. I czem są ruscy, którzy o sobie mówią, iż są gente Rutheni, natione Moscovitae? Wszakże Moskalami. A zatem także ci, co o sobie mówią, iż są gente Rutheni, natione Poloni, są już na mocy nieubłaganej logiki nie Rusinami, lecz Polakami. I zdruzgotaliśmy sakramentalną formułkę, którą prawdziwego Rusina wprzód mierzono, która wieki przetrwała, ale już prawdzie nie odpowiadała, a przyznaliśmy odrębność narodową Rusinów ${ }^{48}$.

W obliczu konfliktu narodowościowego należało się opowiedzieć po jednej lub drugiej stronie konfliktu, polskiej lub ukraińskiej. Co prawda istnienie ludności o tożsamości typu gente Rutheni, natione Poloni przemawiało za realizacją koncepcji federacyjnej mającej pewne szanse powodzenia tuż po pierwszej wojnie światowej, ale w rzeczywistości koncepcja ta szybko ustąpiła miejsca koncepcji Polski zmierzającej w kierunku asymilacji rozmaitych grup etnicznych. Ostatni manifest ideowy gente Rutheni, natione Poloni to traktat byłego posła Sejmu Krajowego Teofila Merunowicza z 1919 roku, zatytułowany Sprawa ruska i kongres pokojowy ${ }^{49}$. W tekście tym autor przypominał historię Rusinów narodowości polskiej, odwołując się do tradycji unii lubelskiej, i postulował utworzenie federacji Polski, Litwy i Rusi, który to projekt miał stanowić odpowiedź na wojnę polsko-ukraińską o Galicję Wschodnią.

Był to de facto ostatni polityczny głos zanikającej z przestrzeni publicznej grupy gente Rutheni, natione Poloni. Nie oznacza to bynajmniej, że ludzie reprezentujący taką dwuszczeblową tożsamość zniknęli zupełnie, wręcz przeciwnie, przecież Polacy i Rusini w dalszym ciągu zamieszkiwali wspólnie to samo terytorium, wzajemnie na siebie oddziaływali, dochodziło do małżeństw mieszanych itd. Polityka w niepodległym państwie polskim siłą rzeczy była jednak nakierowana na asymilację ludności niepolskiej. Polityce takiej służyło miedzy innymi pismo „Greko-Katolik” (później ukazujące się pod tytułami: „Greko-Polak” i „Polak Greko-Katolik”), które jawnie odwoływało się do hasła gente Rutheni, natione Poloni, lecz w rzeczywistości promowało ono polonizację ludności greckokatolickiej przy zachowaniu jej odrębności obrządkowej. W założeniu grekokatolik miał już nie być Rusinem, a tym bardziej

46 Ibidem, s. 987 (24. posiedzenie z 26 XI).

47 Zob. М. Мудрий, „Русини польської нації” (gente Rutheni, natione Poloni) в Галичині XIX cm. і поняття „вітчизни”, „Україна. Культурна спадщина, національна свідомість, державність” 2006-2007, вип. 15: Confraternitas. Юбілейний збірник на потану Ярослава Ісаєвича, s. 471.

48 [J. Czerwiński], O Rusinach i dla Rusinów, Kraków 1891, s. 4.

49 T. Merunowicz, Sprawa ruska i kongres pokojowy. Referat, opracowany dla Polskiego Biura Prac Kongresowych, Lwów 1919. 
Ukraińcem, ale Polakiem obrządku greckokatolickiego. Pierwszy numer pisma z 1934 roku objaśniał:

„Greko-Katolik” ma na celu obronę polskiej tradycji, polskiego kierunku narodowego i państwowego wśród grecko-katolickich obywateli w Polsce, uważających się za Polaków, który to kierunek wyrażał się ongiś hasłem: „Gente Ruthenus - natione Polonus” (,Rusin z rodu - Polak z narodu"). Pragnie wznowić, wzmocnić i utrzymać polskiego ducha wśród starszej generacji, wychowanej po polsku, pragnie również utrzymać tego ducha wśród młodszej generacji, ich dzieci. Pismo nasze wreszcie postawiło sobie za cel zaznajamiać społeczeństwo polskie z zagadnieniem greko-katolicyzmu i ruskości, zbliżyć z powrotem jednych i drugich, gr.-katolikow do polskości i polskość do grecko-katolicyzmu, jak ongiś polski naród składał się z dwóch równorzędnych i równouprawnionych części, choć różnych obrządkowo: rzymskich i greckich katolików, pragnie, by wielka idea naszych ojców znów zapanowała we wskrzeszonej Polsce w szeregach naszych zachwianych pod tym względem przez zaborców ${ }^{50}$.

W takim duchu utrzymane były liczne teksty ukazujące się na łamach periodyku.

Z polityką asymilacyjną wiązała się konieczność ustalenia, jaka jest rzeczywista liczba gente Rutheni, natione Poloni. I tak w 1939 roku Tadeusz Jagmin w pracy Polacy grekokatolicy na ziemi czerwieńskiej obliczał, że Polskę w 1931 roku zamieszkiwała fantastyczna wręcz liczba 430000 Rusinów narodowości polskiej ${ }^{51}$. Było to czterokrotnie więcej, niż jeszcze w 1909 roku szacował inny badacz - Józef Buzek $(107000)^{52}$. Stanisław Pawłowski w opublikowanej w 1919 roku pracy mówił zaś o 235000 takich osób ${ }^{53}$. Widać zatem, że liczba Rusinów narodowości polskiej $\mathrm{w}$ opracowaniach rosła $\mathrm{w}$ związku z rozwojem konfliktu polsko-ukraińskiego i dyskusji o przynależności państwowej obszaru dawnej Galicji Wschodniej. Te rozbieżności w szacunkach nie pozwalają na obiektywne stwierdzenie, ilu faktycznie było ludzi o dwuszczeblowej tożsamości w pierwszej połowie XX wieku na obszarze dawnej Galicji Wschodniej, zdradzają natomiast cele niektórych autorów - chęć opisania jako członków polskiej narodowości jak największej liczby osób niepolskiego pochodzenia etnicznego.

Jeśli chodzi o literaturę naukową, to trudno przedstawiać tutaj cały stan badań nad omawianym zagadnieniem; wspomnijmy tylko przedwojenną jeszcze pracę, której autor zjawisko gente Rutheni, natione Poloni potraktował jako obiekt badawczy, sięgając do dziejów XVI-wiecznej Polski. Mowa o opracowaniu Stanisława Kota poświęconym problemowi świadomości narodowej w Rzeczypospolitej Obojga Narodów ${ }^{54}$. Wspomniana praca okazała się bardzo ważna dla dalszego rozwoju badań nad formacją Rusinów narodowości polskiej, bowiem Kot zdefiniował, czym było zjawisko gente Rutheni, natione Poloni. Jego słowa o tym, jak ,gentes poszczególne zlewały się w jedną natio, która nie oznaczała jak dawniej obywateli jednego

so Od Wydawnictwa, „Greko-Katolik” 1934, nr 1 z III, s. 1.

51 T. Jagmin, Polacy grekokatolicy na ziemi czerwieńskiej, Lwów 1939, s. 7.

52 J. Buzek, Rozsiedlenie ludności Galicyi wedtug wyznania i języka, Lwów 1909, s. 156.

53 S. Pawłowski, Ludność rzymsko-katolicka w polsko-ruskiej części Galicji z dwoma mapami, Lwów 1919, s. 12.

54 S. Kot, Świadomość narodowa w Polsce w. XV-XVII, „Kwartalnik Historyczny” R. 52, 1938, z. 1, s. 15-33. 
państwa, choć różnego pochodzenia i języka, ale obywateli zjednoczonych w jednej wspólnocie języka, instytucyj, a co najważniejsza - jednej polskiej świadomości narodowej" 55 , weszły na stałe do literatury przedmiotu i były niejednokrotnie przywoływane nie tyle nawet przez badaczy dziejów rozbiorowych, ile - przede wszystkim - przez historyków podejmujących temat sytuacji społecznej w Rzeczypospolitej Obojga Narodów. Odtąd owo pojęcie było i jest wykorzystywane do opisu szlachty ruskiej w Polsce przedrozbiorowej ${ }^{56}$. Warto jednak nadmienić, iż ostatnio zarzuca się Kotowi, że na podstawie przypisywanej Orzechowskiemu etykiety gente Rutheni, natione Poloni wykreował on de facto koncept wieloetnicznego „,narodu politycznego" dawnej Rzeczypospolitej Obojga Narodów ${ }^{57}$.

Ale oprócz historiografii, gente Rutheni, natione Poloni rozpoczęli wieść swój żywot także w literaturze wspomnieniowej. Po drugiej wojnie światowej - której skutkiem było przekształcenie Polski w kraj niemal jednolity narodowo - Rusini narodowości polskiej stali się także jednym z wielu elementów pamięci po utraconych Kresach, tym razem tych najbliższych - Małopolsce Wschodniej. Lwowski bibliofil Mieczysław Opałek nostalgicznie wspominał swoich ruskich krewnych, będących dla niego przykładnymi Rusinami narodowości polskiej, takimi jak Platon Kostecki, którego wiersz Nasza molytwa zacytował w swoich wspomnieniach ${ }^{58}$. Nie on jeden. Gente Rutheni, natione Poloni stali się elementem krajobrazu kulturowego Galicji, który przestał istnieć w rzeczywistości, przeniósł się zaś do krainy wyobraźni potomków mieszkańców tych ziem. Ale to już zupełnie inna historia.

\section{BIBLIOGRAFIA}

\section{I. Źródła}

\section{1. Źródła archiwalne}

Zakład Narodowy im. Ossolińskich we Wrocławiu:

mps 13535/II (MF 3269): M. Opałek, Książka o Lwowie i mojej młodości. Kartki z pamiętnika 1881-1901, Frysztak 1958.

55 Ibidem, s. 26-27.

56 Zob. np.: T. Chynczewska-Hennel, Świadomość narodowa szlachty ukraińskiej i kozaczyzny od schytku XVI do polowy XVII w., Warszawa 1985, s. 133-146; eadem, Gente Ruthenus - Natione Polonus, „Warszawskie Zeszyty Ukrainoznawcze” 1998, t. 6-7: Spotkania polsko-ukraińskie. Studia Ucrainica, red. S. Kozak, s. 35-44.

57 Por. m.in.: D. Althoen, op. cit., s. 475-476, przyp. 3; W. Pawlikowska-Butterwick, A 'Foreign' Elite? The Territorial Origins of the Canons and Prelates of the Cathedral Chapter of Vilna in the Second Half of the Sixteenth Century, ,Slavonic and East European Review” (London) vol. 92, 2014, no. 1, s. 51, przyp. 26.

58 Zakład Narodowy im. Ossolińskich we Wrocławiu, mps 13535/II (MF 3269): M. Opałek, Książka o Lwowie i mojej młodości. Kartki z pamiętnika 1881-1901, Frysztak 1958, s. 15-16. 
Львівська національна наукова бібліотека України імені В. Стефаника (ЛННБУ): ф. 5: Zbiór rękopisów, oп. 1, 3063/II: P. Kostecki, W sprawie ruskiej, [Lwów 1863].

\section{2. Źródła drukowane}

Adres Rusinów, [Lwów 1848].

Cięglewicz K., Rzecz czerwono-ruska 1848 roku, Lwów 1848.

[Czerwiński J.], O Rusinach i dla Rusinów, Kraków 1891.

[Horoszkiewicz J.], Gente Ruthenus, natione Polonus. Podstawa do zgody w narodzie, Lwów 1871.

Merunowicz T., Pamiatka 300-litnoj ricznyci Unii Lublińskoj 1869 roku, [Lwów 1869].

Merunowicz T., Pamiatka 300-letniej rocznicy Unii Lubelskiej 1869 roku, Lwów 1869.

Merunowicz T., Sprawa ruska i kongres pokojowy. Referat, opracowany dla Polskiego Biura Prac Kongresowych, Lwów 1919.

Stenograficzne sprawozdania z drugiej sesyi szóstego peryodu Sejmu krajowego Królestwa Galicyi i Lodomeryi z Wielkiem Księstwem Krakowskiem z roku 1890, Lwów 1890.

Stenograficzne sprawozdania z trzeciej sesyi Sejmu Krajowego Królestwa Galicyi i Lodomeryi wraz z Wielkiem Księstwem Krakowskiem w roku 1865-1866, t. 1: Posiedzenie 1-40; t. 2: Posiedzenie 41-80, Lwów 1865-1866.

Vita Stanislai Orichovii gente Rutheni, natione Poloni ad Ioannem Franciscum Commendonum anno MDLXIV scripta, [Kraków 1891].

\section{Wspomnienia, pamiętniki}

[Baranowski I.], Pamiętniki Ignacego Baranowskiego (1840-1862), wyd. A. Wrzosek, Poznań 1923.

Doboszyński J., Pamiętnik [w:] Pamiętniki urzędników galicyjskich, przyg. do dr. I. Homola, B. Łopuszański, Kraków 1978, s. 364-365.

Matkowski J., Zbiór niektórych szczegółów życia mego, przedm. R. Grabowski [w:] Pamiętniki z lat 1792-1849, oprac. R. Grabowski, Wrocław 1961, s. 95-176.

Słotwiński A., Wspomnienia z niedawnej przeszłości, cz. 1: 1860-1871, Kraków 1892.

\section{Utwory literackie}

Kostecki P., Poezyi, Lwów 1862.

[Łewyćkyj O.] Ostap Kowbasiuk, gente Ruthenus, natione także Ruthenus, Uciekinierzy, poemat à la ,Konrad Wallenrod”, Lwów 1863).

Mickiewicz A., Księgi narodu polskiego i pielgrzymstwa polskiego, Paryż 1832.

Zaleski B., Poezija, Paryż 1841.

\section{Prasa}

„Czas" (Kraków) 1899.

„Dnewnyk Ruskij” (Lwów) 1848.

„Gazeta Narodowa” (Lwów) 1888. 
„Greko-Katolik” (Kraków) 1934.

„Przegląd Powszechny” (Lwów) 1861.

\section{Opracowania}

Althoen D., Natione Polonus and the Narod szlachecki. Two Myths of National Identity and Noble Solidarity, „Zeitschrift für Ostmitteleuropa-Forschung” 2003, Bd. 52, s. 475-508.

Buzek J., Rozsiedlenie ludności Galicyi wedtug wyznania i języka, Lwów 1909.

Chlebowczyk J., O prawie do bytu małych i młodych narodów. Kwestia narodowa i procesy narodotwórcze we wschodniej Europie Środkowej w dobie kapitalizmu (od schytku XVIII do początków XX w.), Warszawa-Kraków 1983.

Chynczewska-Hennel T., Gente Ruthenus - Natione Polonus, „Warszawskie Zeszyty Ukrainoznawcze” 1998, t. 6-7: Spotkania polsko-ukraińskie. Studia Ucrainica, red. S. Kozak, s. 35-44.

Chynczewska-Hennel T., Świadomość narodowa szlachty ukraińskiej i kozaczyzny od schytku XVI do połowy XVII w., Warszawa 1985.

Estreicher S., Bibliografia polska, t. 23, Kraków 1910.

Jagmin T., Polacy grekokatolicy na ziemi czerwieńskiej, Lwów 1939.

Kot S., Świadomość narodowa w Polsce w. XV-XVII, „Kwartalnik Historyczny” R. 52, 1938, z. 1, s. 15-33.

Kubala L., Stanisław Orzechowski i wplyw jego na Rzeczpospolite wobec reformacji XVI wieku. Rzecz historyczna, Lwów 1870.

Kultura pogranicza wschodniego. Zarys encyklopedyczny, red. T. Budrewicz, T. Bujnicki, J.S. Ossowski, Warszawa 2011.

Łopuszański B., Matkowski Józef [w:] Polski słownik biograficzny, t. 20, Wrocław-Warszawa-Gdańsk-Kraków 1975, s. 203.

Łoziński B., Agenor hrabia Gotuchowski w pierwszym okresie rządów swoich (1846-1859), Lwów 1901.

Moklak J., Spór polsko-ukrainski o język obrad sejmu galicyjskiego (1865-1866). Wnioski Antona Petruszewycza i Aleksandra Borkowskiego. Przyczynek do ksztaltowania się nacjonalizmów w Galicji Wschodniej, „Biuletyn Ukrainoznawczy” 2003, t. 9, s. 40-51.

Moklak J., Stanowisko postów polskich gente Ruthenus i ruskich (ukraińskich) w Sejmie Krajowym galicyjskim wobec projektu ustawy o języku wykładowym w szkołach ludowych i średnich w 1866 r., „Biuletyn Ukrainoznawczy” 2002, t. 8, s. 28-41.

Mudryj M., Dylematy narodowościowe w Sejmie Krajowym galicyjskim (na przykładzie posłów formacji gente Rutheni natione Poloni) [w:] Ukrainskie tradycje parlamentarne. XIX-XXI wiek, red. J. Moklak, Kraków 2006, s. 59-94.

Mudryj M., Powstanie styczniowe a środowisko gente Rutheni, natione Poloni w Galicji [w:] Powstanie styczniowe. Odniesienia, interpretacje, pamięć, red. T. Kargol, Kraków 2013, s. 67-78.

Osadczy W., Święta Ruś. Rozwój i oddziatywanie idei prawosławia w Galicji, Lublin 2007.

Pawlikowska-Butterwick W., A 'Foreign'Elite? The Territorial Origins of the Canons and Prelates of the Cathedral Chapter of Vilna in the Second Half of the Sixteenth Century, „Slavonic and East European Review” vol. 92, 2014, no. 1, s. 44-80.

Pawłowski S., Ludność rzymsko-katolicka w polsko-ruskiej części Galicji z dwoma mapami, Lwów 1919. 
Sienkiewicz K., Skarbiec historii polskiej, t. 1, Paryż 1839.

Sierżęga P., Obchody rocznicy unii lubelskiej na terenie Galicji w 1869 roku [w:] Dziatalność wyzwoleńcza, red. J. Hoff, Rzeszów 2001, Galicja i Jej Dziedzictwo, t. 15, s. $146-192$.

Śladkowski W., Pod znakiem Orła, Pogoni i Michała Archanioła. Idee unijne i federacyjne w dobie powstania styczniowego [w:] Unia lubelska. Unia Europejska, red. I. Hofman, Lublin 2010, s. 132-149.

Świątek A., Gente Rutheni, natione Poloni. Z dziejów Rusinów narodowości polskiej w Galicji, Kraków 2014.

Świątek A., Polacy i Rusini o Zjeździe Słowiańskim w Pradze w 1848 roku, „Historica. Revue pro historii a př́buzné vědy" R. 7, 2016, nr 1, s. 23-52.

Wój towicz-Huber B., ,, Ojcowie narodu”. Duchowieństwo greckokatolickie w ruchu narodowym Rusinów galicyjskich (1867-1918), Warszawa 2008.

Zięba A.A., Gente Rutheni, natione Poloni [w:] Prace Komisji Wschodnioeuropejskiej, t. 2, red. R. Łużny, A.A. Zięba, Kraków 1995, s. 61-77.

Вендланд А.В., Русофіли Галичини. Українські консерватори між Австрією та Росією 1848-1915, перекл. Х. Назаркевич, наук. ред. М. Мудрий, Львів 2015.

Мудрий М., „Jesteśmy rozdwojonymi członkami jednego ciała”. До питання про відносини між Головною Руською Радою і Руським Собором 1848 року [w:] Записки Наукового товариства імені Шевченка, т. 265: Прачі Історично-філософської секиії, Львів 2013, s. 54-80.

Мудрий М., Ідея польсько-української унії та „Русини польської нації” в етнополітичному дискурсі Галичини 1859-1869 років, „Вісник Львівського університету. Серія історична" 2005, вип. 39-40, s. 83-148.

Мудрий М., „Русини польської націï” (gente Rutheni, natione Poloni) в Галичині XIX cm. і поняття , вітчизни”, „Україна. Культурна спадщина, національна свідомість, державність" 2006-2007, вип. 15: Confraternitas. Юбілейний збірник на пошану Ярослава Ісаєвича, s. 461-474.

Мудрий М., Руський собор 1848 року. Історіографічний та джерелознавчий огляд, „Вісник Львівського університету. Серія книгознавство, бібліотекознавство та інформаційні технологіi” 2014, вип. 8, s. 193-206.

Мудрий М., Руський собор 1848 року. Організація та члени, „Україна. Культурна спадщина, національна свідомість, державність” 2008, вип. 16: Юбілейний збірник на пошану Івана Патера, s. 107-126.

Орлевич I., Ставропігийський інститут у Львові (кінец̧ь XVIII-60-i pp. XIX cm.), Львів 2000.

Плохій С., Походження слов янських націй. Домодерні ідентичності в Україні, Росії та Білорусі, Київ 2015.

Франко I., Стара Русь [w:] Зібрання творів у п `ттесяти томах, т. 37: Літературнокритичні праці (1906-1908), Київ 1982, s. 79-110. 